\title{
CAN THE COMPANY ACHIEVE PROFITABILITY THROUGH THE APPLICATION OF CAPITAL STRUCTURE FORMULATIONS? A CASE STUDY OF COMPANIES REGISTERED WITH THE JAKARTA ISLAMIC INDEX / JII
}

\author{
Zein Aldi Bakhtiar, Alexandri M. Benny, Suryanto \\ Postgraduate Program of Business Administration, Faculty of Social and Politic Science, \\ University of Padjadjaran, Bandung, Indonesia \\ *E-mail : aldi15002@mail.unpad.ac.id
}

\begin{abstract}
Capital structure is an integral combination of third party funding flows with internal capital that is fully used to finance the company's operational activities. Capital structure theory is important to analyze because it can affect the amount of capital costs paid. The measurement of capital structure in this study uses Debt to Total Assets (DAR) to assess the composition of debt in corporate funding and Debt to Equity Ratio (DER) which reflects the combination of debt and own capital. Profitability shows the company's ability to generate profits. Profitability ratios are used to measure the company's performance in generating profits. Return on Equity (ROE) reflects the company's performance based on the perspective of the shareholders. In sharia-based business classifications, measuring the effect of capital structure on company profitability is very interesting to study. The application of sharia principles in countries with the largest Muslim population in the world has experienced significant development. The concept of economic sharia is not only seen as a religious identity that is inclusive, but has become an important alternative worth considering besides the secular business model. This study aims to determine the extent to which capital structure affects the profitability of companies that meet the best sharia and economic criteria on the Indonesia Stock Exchange (IDX). The best companies are listed in the Jakarta Islamic Index (JII). There are 17 companies included in the criteria of this study in the period 2012 to 2017. The method used in this study is multiple regression analysis. The results showed that DAR had a significant negative effect on ROE. Whereas DER has a significant positive effect on profitability as measured by ROE. Simultaneously, the measurement variable Capital Structure, namely DAR and DER significantly influences profitability as measured by ROE.
\end{abstract}

\section{KEY WORDS}

Capital structure, debt assets ratio (DAR), debt equity ratio (DER), profitability, econonic sharia, stock exchange, return on equity (ROE).

Funding aspects play a fundamental role in carrying out company operational activities. Companies are encouraged to be able to design funding schemes to finance various expenditure items that have been set. Funding schemes will generally involve third parties, it is difficult to find companies that are able to finance the company's operations independently. There are many aspects that need to be considered in determining an ideal funding scheme for a company, such as the amount of funds needed, the type of assets financed, the term of payment, the cost of capital, the operating cycle and others. Each funding scheme used will have different risk and profit implications.

The company's financial manager must be more careful in establishing capital structure in order to increase the company's value and reputation in the eyes of investors or creditors so that they are superior in the face of increasingly competitive business competition. One of the company's goals in the long run is to optimize company value. The higher the value of the company, is linearly proportional to the more prosperous the owner of the company.

Capital structure is very important for the firm because it is related to the ability to meet the needs of stakeholders. The theories of capital structure include trying to provide a work concept to understand how financial decisions are made (Yildirim.et.al, 2018). Measurement of capital structure including using the debt to equity ratio that reflects a combination of debt 
and capital to increase the value of the firm (Usman \& Saleem, 2014). Boopen (2014) uses debt to total assets to measure the level of debt structure in a firm's funding

Jakarta Islamic Index (JII) is an index that contains 30 best Islamic criteria listed firms that have the highest market capitalization and good financial performance. Issuers in this index generally come from the infrastructure, consumption and commodity sectors in line with established sharia rules. Its members are renewed every 6 months in January and July.

This study seeks to describe and analyze phenomena that occur in Jll through a benchmark approach (comparison) with non-sharia shares that have high liquidity and high market capitalization and are supported by good corporate fundamentals where the proxies that are often used by investors related to these criteria are LQ45 index. There are 45 listed firms or shares listed in this index. Below is the comparison chart between firms incorporated in JII and LQ45, among others, as follows.

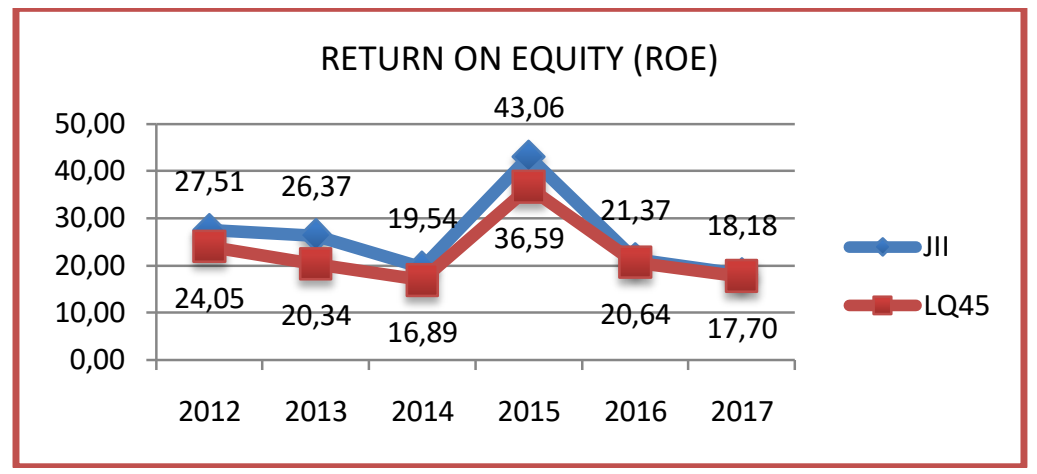

Figure 1 - Return on Equity JII and LQ45

Figure 1 above reflects that the level of profitability as measured through return on equity (ROE), the firms incorporated in JII are higher than LQ45. Noted, the ROE value of JII firms was 27.51 in 2012, the difference was 3.46 with LQ45, which was 24.05. In 2017, the value of ROE JII is still higher than LQ45, namely 18.18 and 17.70 with a difference of 0.48 . This condition indicates that firms that are members of $\mathrm{JII}$ have a better level of profitability compared to firms that are members of LQ45.

Nawaz et. al (2011) researched the Pakistan Textile Industry to examine whether there are an influence and relationship between capital structure and firm performance. The results of the study stated that the capital structure measured using DER has a positive influence on firm performance measured through Return on Equity (ROE).

Hasbi (2015) also researched by examining 152 Islamic Islamic microfinance institutions, namely Baitul Maa wat Tamwil (BMT) in 12 provinces including on the islands of Java, Sumatra, Kalimantan, and Sulawesi. The results of this study are the capital structure measured using DAR significantly positive effect on profitability as measured using ROE.

Besides, Boopen (2014) conducted a research result stating that firm performance is influenced by capital structure, business risk, firm size, and exchange rate. Growth opportunities, free cash flow, age of firm, price of oil do not produce a significant effect on firm performance as measured by ROA and ROE while the capital structure uses DAR.

This study aims to determine the effect of capital structure measured using a debt asset ratio and a debt equity ratio both partially and simultaneously on the profitability of firms included in the sharia category in Indonesia.

\section{METHODS OF RESEARCH}

Data collection is sourced from secondary data published by the Indonesia Stock Exchange which is then verified with other authorities who have other interests and authorities in order to complete it. The population in this study is companies listed on the Jakarta Islamic Index (JII) on the Indonesia Stock Exchange for the 2012-2017 period. Sharia stock review which is a Jll constituent is carried out twice a year, in May and 
November, following the schedule of Sharia Securities List review determined by the Indonesian Financial Services Authority regarding Criteria and Issuance of Sharia Securities List. Then IDX determines and selects sharia shares that are JII constituents so that there are shares that enter and exit the JII list. In other words, there were 11 publications of the results of the review that were announced by the Indonesia Stock Exchange in the period that will be examined by researchers, namely precisely from the first publication in June 2012 to the last publication in November 2017. There are 51 companies that have been listed in the that time period so that it is determined to be the study population. Then the purposive sampling technique is used certain considerations or criteria that must be met by the samples used in this study.

The considerations are as follows:

- Companies listed on the Jakarta Islamic Index (JII) on the Indonesia Stock Exchange for the 2012-2017 period which are at least 10 times out of 11 entries based on the Indonesian Stock Exchange criteria;

- Companies listed on the Jakarta Islamic Index (JII) on the Indonesia Stock Exchange for the 2012-2017 period that have complete financial statements and are related to research variables.

After the selection process was carried out, 17 companies were obtained that were in accordance with established criteria and subsequently determined as samples.

\section{LITERATURE REVIEW}

Capital structure is the composition or composition of the debt and capital mix. Debt consists of long-term and short-term debt. While capital consists of ordinary shares, preferred shares, and retained earnings. The capital structure shows how a firm can finance all of its business activities through debt, equity, and securities. Everything is processed in such a way as to make an optimal composition taking into account all obligations (Nawaz et.al, 2011). In this study capital structure is measured using a debt assets ratio and debt equity ratio.

According to Boopen (2014), the debt to asset ratio (DAR) aims to find out how far the debt is in financing the firm. The higher this ratio means the greater the amount of loan capital used to prop up assets to generate profits for the firm. The formula for calculating debt to asset ratio (DAR) according to Boopen (2014) is as follows:

\section{Debt to total assets $=$ total liabilities $/$ total assets}

Based on the theoretical basis mentioned above, researchers use debt to equity ratio and debt to asset ratio in measuring capital structure. Following research conducted by Nawaz et.al (2011), Talib (2014), Boopen (2014), and Usman \& Saleem (2015).

Debt to Equity Ratio (DER) is a comparison between total debt and equity. This ratio shows the ability of the firm's own capital to meet and sustain its obligations. Usman \& Saleem (2015), capital structure is measured using debt to equity ratio. Furthermore, according to Nawaz et.al (2011) capital structure theory explains that corporate funding policies consist of a combination of debt and capital which aims to increase the value of the firm. The formula for calculating the debt to equity ratio according to Nawaz et.al (2011) is as follows:

$$
\text { Debt to equity ratio }=\text { total liabilities } / \text { shareholders equity }
$$

Profitability is a ratio that shows a firm's ability to generate profits during a certain period and also provides an overview of the effectiveness of management in carrying out its operations.

This study uses a ratio of return on equity (ROE) to measure the profitability of a firm because this ratio reflects the ability of a firm or issuer to manage its equity. This ratio is also often used by shareholders to assess the firm's performance and measure the amount of 
return on capital to be obtained. So that the greater the number of these ratios then shows the ability of good firm performance and becomes a concern and attraction for investors in investing. Dwilaksono (2010), Usman \& Sana (2015), Hasbi (2015), and Yildirim et.al. (2018). The ROE formula can be stated as follows:

Return on equity = net income/shareholder equity

Table 1 - Variable Classification

\begin{tabular}{|c|c|c|}
\hline Classification & Variable & Indicator \\
\hline \multirow{2}{*}{ Capital Structure (Independent Variable) } & Debt to Asset Ratio (DAR) (X1) & Total Debt and Total Assets \\
\cline { 2 - 3 } & Debt to Equity Ratio (DER) (X2) & Total Debt and Total Own Equity \\
\hline Profitabilitability (Dependent Variable) & Return on Equity (Y) & Earning After Tax and Own Equity \\
\hline
\end{tabular}

Seventeen firms become the sample of this study based on observations of the best issuers or sharia stocks that are consistently listed on the Jakarta Islamic Index (JII) on the Indonesia Stock Exchange (IDX). The sampling technique uses a non-probability purposive sampling method. Data collection uses the secondary data documentation study method collected from the Indonesia Stock Exchange (IDX) related to the types of financial statement data and firm publications included in JII or the best collection of Islamic shares.

Analysis of research data using multiple linear regression previously tested classic assumptions consisting of normality test, multicollinearity test, and heteroscadacity test.

\section{RESULT AND DISCUSSION}

The research object observed was for six years (2012-2017) and then made an average value of the variable or object in that period so that the value of the variable would appear to be analyzed further as described in Appendix 1. The method is in line with the research conducted by Hasbi (2015) and Nawaz et.al (2011).

Table 2 - Normality Test (Kolgomorov-Smirnov)

\begin{tabular}{|c|c|c|}
\hline \multicolumn{2}{|c|}{$n / n$} & Unstandardized Residual \\
\hline \multicolumn{2}{|l|}{$\mathrm{N}$} & 17 \\
\hline \multirow[t]{2}{*}{ Normal Parameters ${ }^{a, b}$} & Mean & .0000000 \\
\hline & Std. Deviation & 14.62352957 \\
\hline \multirow[t]{3}{*}{ Most Extreme Differences } & Absolute & .115 \\
\hline & Positive & .074 \\
\hline & Negative & -.115 \\
\hline \multicolumn{2}{|l|}{ Test Statistic } & .115 \\
\hline \multicolumn{2}{|l|}{ Asymp. Sig. (2-tailed) } & $.200^{\mathrm{c}, \mathrm{d}}$ \\
\hline
\end{tabular}

a. Test distribution is Normal.

b. Calculated from data.

c. Lilliefors Significance Correction.

d. This is a lower bound of the true significance.

Source: Data Processed.

From the Kolmogorov-Smirnov normality test table above it can be concluded that the data to be examined is normally distributed because the significance value of 0.200 is greater than $\alpha=0.05$, so it is included in the regression modeling criteria.

\begin{tabular}{|c|c|c|c|c|c|c|c|c|}
\hline \multirow[b]{3}{*}{ Model } & \multicolumn{8}{|c|}{ Coefficients $^{\mathrm{a}}$} \\
\hline & & \multicolumn{2}{|c|}{ Unstandardized Coefficients } & \multirow{2}{*}{$\begin{array}{l}\text { Standardized } \\
\text { Coefficients } \\
\text { Beta }\end{array}$} & \multirow[b]{2}{*}{$t$} & \multirow[b]{2}{*}{ Sig. } & \multicolumn{2}{|c|}{ Collinearity Statistics } \\
\hline & & B & Std. Error & & & & Tolerance & VIF \\
\hline 1 & (Constant) & 47.810 & 18.353 & & 2.605 & .021 & & \\
\hline & DAR & -337.320 & 114.434 & -2.155 & -2.948 & .011 & .044 & 22.507 \\
\hline & DER & 145.891 & 38.288 & 2.786 & 3.810 & .002 & .044 & 22.507 \\
\hline
\end{tabular}

Source: Data Processed. 
The Tolerance value for the DAR and DER variables is the same, which is equal to 0.044 . Because the value of the tollerance of the two variables is not greater than 0.01 , it can be said that there is no multicollinearity in the two variables so that it includes the criteria in the regression analysis.

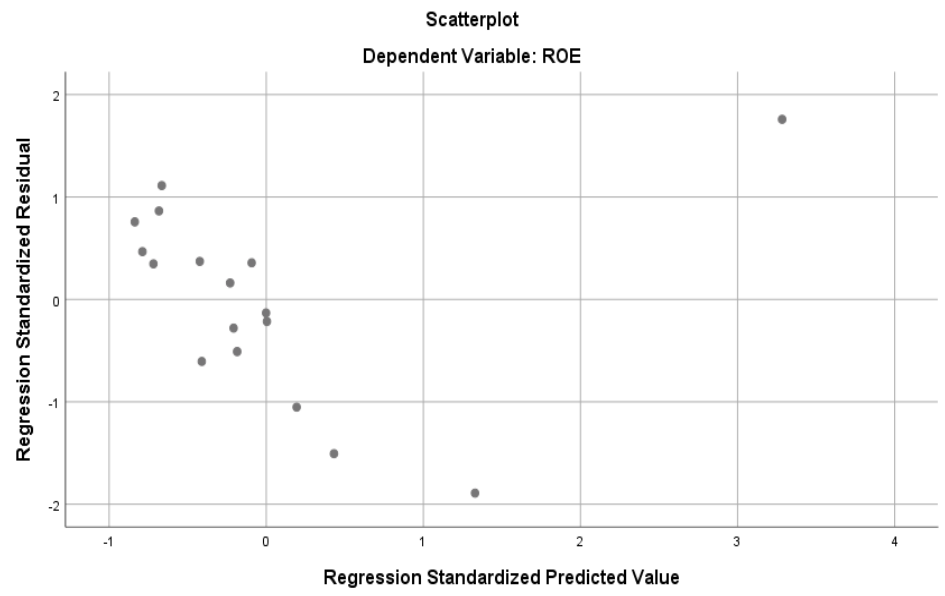

Figure 2 - Heteroscedasticity Test (Source: Data Processed)

Scatter plot picture above is known that the points do not form clear patterns, spread above and below the number 0 on the $\mathrm{Y}$-axis. So, it can be concluded that there is no heteroscedasticity in the regression model.

Table 4 - Multiple Regression Analysis

Coefficients $^{\mathrm{a}}$

\begin{tabular}{|c|c|c|c|c|c|}
\hline \multirow[b]{2}{*}{ Model } & \multicolumn{2}{|c|}{ Unstandardized Coefficients } & \multirow{2}{*}{$\begin{array}{c}\text { Standardized Coefficients } \\
\text { Beta }\end{array}$} & \multirow[b]{2}{*}{$\mathrm{t}$} & \multirow[b]{2}{*}{ Sig. } \\
\hline & \begin{tabular}{l|l}
$\mathrm{B}$ & \\
\end{tabular} & Std. Error & & & \\
\hline 1 (Constant) & 47.810 & 18.353 & & 2.605 & .021 \\
\hline DAR & -337.320 & 114.434 & -2.155 & -2.948 & .011 \\
\hline DER & 145.891 & 38.288 & 2.786 & 3.810 & .002 \\
\hline
\end{tabular}

a. Dependent Variable: ROE.

Source: Data Processed.

The equation or regression model obtained from data processing using SPSS Version 25 Software in Table 4 is as follows:

$$
Y=a+b 1 \times 1+b 2 \times 2
$$

Where: $Y$ - ROE (\%) to be predicted; $A$ - constant ( $Y$ value if $x 1, x 2=0)$; b1 b2 - regression coefficient; $x 1$ - DAR; x2 - DER.

The interpretation of the regression model above is as follows:

- A constant of 47.81 implies that if DAR (x1) and DER (x2) the value is 0 , then ROE $(\mathrm{Y})$ is 47.81 ;

- The regression coefficient of the DAR variable (b1) is -337.32, meaning that if other independent variables have a fixed value and the DAR has increased by 1 , the ROE value will decrease by -337.32 . A negative coefficient value means that there is a contradictory influence between the independent and dependent variables. If the DAR value increases, conversely the ROE value decreases;

- The regression coefficient of the DER variable (b2) is 145.89 which means that if the other independent variables are fixed and the DER value increases 1 , the ROE value will increase by 145.89 . A positive regression coefficient value means there is a direct relationship between DER and ROE. if DER increases, ROE also increases. 
The coefficient of determination has a function to determine the contribution of the influence of DAR and DER variables on ROE. The following results of the analysis of the coefficient of determination.

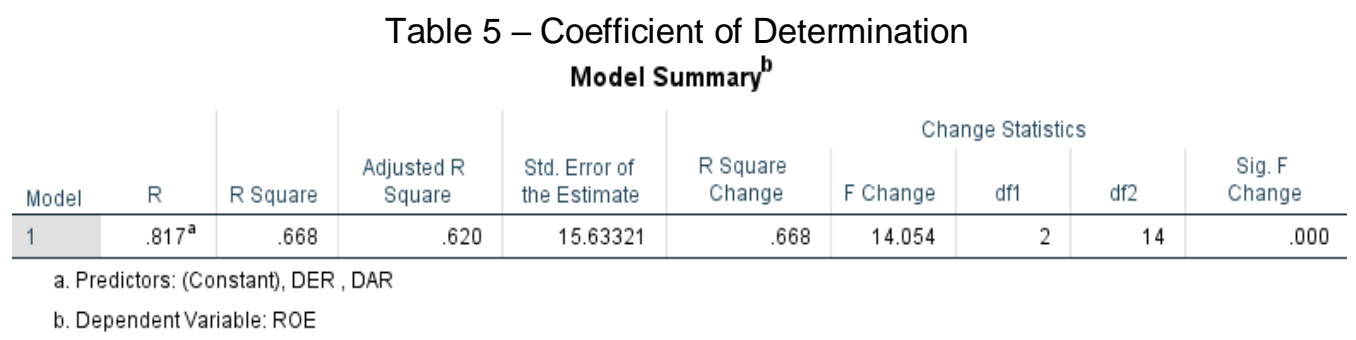

Source: Data Processed.

It is known that the $R$ Square coefficient value is 0.668 obtained from the square of the correlation coefficient $(R)$ value that is 0.817 . The coefficient of determination of 0.668 or equal to $66.8 \%$ implies that the DAR variable and the DER variable contribute to the ROE variable of $66.8 \%$. While the rest, ie $33.2 \%(100 \%-66.8 \%)$ is influenced by other variables outside this regression equation or variables not examined.

Table 6 - Partial Hypothesis Test (t-Test)

\begin{tabular}{|l|c|c|c|}
\hline \multicolumn{2}{|c|}{ Coefficients $^{\mathrm{a}}$} \\
\hline \multirow{2}{*}{ Model } & $T$ & Sig. \\
\hline \multirow{3}{*}{1} & (Constant) & 2.605 & .021 \\
\cline { 2 - 4 } & DAR & -2.948 & .011 \\
\cline { 2 - 4 } & DER & 3.810 & .002 \\
\hline
\end{tabular}

Dependent Variable: ROE.

Source: Data Processed.

The hypothesis of this study is:

- First Hypothesis:

$\mathrm{HO}: \mu 1 \geq \mu 2$.

H0: Debt to Asset Ratio (DAR) does not significantly influence the Return On Equity (ROE) of firms listed on the Jakarta Islamic Index (JII) on the Indonesia Stock Exchange for the 2012-2017 Period.

$\mathrm{H} 1: \mu 1>\mu 2$.

H1: Debt to Asset Ratio (DAR) significantly influences Return on Equity (ROE) in firms listed on the Jakarta Islamic Index (JII) on the Indonesia Stock Exchange for the 2012-2017 Period

The significance value of the DAR variable is 0.011 smaller than the significance level of $0.05(\alpha=0.05)$, then the Debt Assets Ratio (DAR) has a significant effect on ROE. On the other hand, the value of the regression coefficient and $t$ arithmetic on the DAR variable is negative, and then there is an inverse effect between DAR and ROE. In conclusion, DAR significantly influences ROE. When DAR increases, ROE decreases. Conversely, if DAR decreases, ROE increases. Thus Hypothesis $1(\mathrm{H} 1)$ is accepted.

- Second Hypothesis:

$\mathrm{H} 0: \mu 1 \geq \mu 2$.

H0: Debt to Equity Ratio (DER) does not significantly influence the Return On Equity (ROE) of firms listed on the Jakarta Islamic Index (JII) on the Indonesia Stock Exchange for the 2012-2017 Period.

$\mathrm{H} 2: \mu 1>\mu 2$.

H2: Debt to Equity Ratio (DER) significantly influences Return on Equity (ROE) in firms listed on the Jakarta Islamic Index (JII) on the Indonesia Stock Exchange for the 2012-2017 Period. 
The significance value of the DER variable is 0.02 smaller than the significance level of 0.05. That is, DER has a significant effect on ROE. The $t$ value and the DER regression coefficient are positive; the effect is directly proportional between DER and ROE. That is, if the DER value increases, the ROE value also increases. Conversely, if the DER value decreases, the ROE value also decreases. In conclusion, DER has a partially significant effect on ROE so $\mathrm{H} 2$ is accepted.

The $F$ statistical test shows whether the independent variable simultaneously influences the dependent variable significantly.

Table 7 - Simultaneous Hypothesis Test (F Test)

ANOVA $^{\mathrm{a}}$

\begin{tabular}{|c|c|c|c|c|c|}
\hline Model & Sum of Squares & Df & Mean Square & $\mathrm{F}$ & Sig. \\
\hline \begin{tabular}{|l|l|}
1 & Regression \\
\end{tabular} & 6869.679 & 2 & 3434.839 & 14.054 & $.000^{\circ}$ \\
\hline Residual & 3421.562 & 14 & 244.397 & & \\
\hline Total & 10291.241 & 16 & & & \\
\hline
\end{tabular}

a. Dependent Variable: ROE

Predictors: (Constant), DER, DAR

Source: Data Processed.

- Third Hypothesis:

$\mathrm{HO}: \mu 1 \geq \mu 2$.

HO: Capital Structure consisting of Debt to Asset Ratio (DAR) and Debt to Equity Ratio (DER) variables do not have a significant simultaneous effect on Return On Equity (ROE) for firms listed on the Jakarta Islamic Index (JII) on the Indonesia Stock Exchange for the 20122017 Period.

H3: $\mu 1>\mu 2$.

H3: Capital Structure consisting of Debt to Asset Ratio (DAR) and Debt to Equity Ratio (DER) variables have a significant simultaneous effect on the Return On Equity (ROE) of firms listed on the Jakarta Islamic Index (JII) on the Indonesia Stock Exchange 2012-2017 period.

The significance value is 0,000 less than the 0.05 significance level and the calculated $F$ value is positive, then Debt to Asset Ratio (DAR) and Debt to Equity Ratio (DER) simultaneously have a positive effect on Return on Equity (ROE). Besides, the F Test that shows the influence of the independent variables simultaneously on the dependent variable is in line with the results of the coefficient of determination that has been described by researchers in the previous discussion. Therefore, the hypothesis (H3) proposed by the researcher mentioned above is accepted.

Hypothesis Test Results show that DAR has a significant effect on ROE. On the other hand, the value of the regression coefficient and $t$ arithmetic on the DAR variable is negative, and then a negative relationship exists between DAR and ROE. In conclusion, DAR has a significant negative effect on ROE. When DAR increases, ROE decreases. Conversely, if DAR decreases, ROE increases.

The relationship and the strong influence of the composition of debt on profitability is a general picture that is always interesting for researchers to be the object of research because the composition of the firm's capital consisting of funds from debt which influence will cause interest expense and funds from activities that are classified in the balance sheet in the capital component. in the form of paid-in capital, ordinary shares, preferences, and retained earnings that will lead to investor returns in the form of dividends is crucial to sustaining a firm in carrying out all its business activities in achieving its goal of obtaining profit. Therefore, in this study, Debt Assets Ratio (DAR) becomes one of the measurements in looking at capital structure. While the firm's ability to generate profits in terms of investors (Shareholders) is measured through ROE.

The results of this study, the capital structure has an impact on the firm to achieve the main goal of maximizing profitability in each of its business activities. Capital composition which triggers the firm's profit to increase is capital obtained from internal strengthening or 
existing in the balance sheet liabilities component of capital. Examples are the issuance of new shares, paid-in profits, and retained earnings. Funds obtained from investors are more profitable than those obtained from creditors. The profit gained because the tax burden is adjusted to the interest expense (tax shield) is not too significant for the interest expense which is the cost of capital to the creditor. In other words, this research means contrary to the classical theory of capital structure, namely trade-off theory, namely, firms tend to add debt because they want to get optimal profits. Debt can reduce the tax burden (tax shield) so that it has an impact on the firm's net profit to be obtained.

This study is in line with Hasbi (2015) and Boopen (2014) who show a negative relationship between DAR and ROE. Therefore, the strong influence between DAR and ROE but negative (contradictory) supports pecking order theory, ie firms tend to strengthen their internal funds by issuing shares and increasing retained earnings because their capital costs are less than raising funds from creditors.

The results of the research on the object under study, namely firms that meet the best sharia compliant on the Indonesia Stock Exchange 2012-2017 observation period show that there is a positive and significant effect between DER and Return on Equity (ROE). This condition is caused by the effectiveness of the firm's management as a representative of shareholders in managing a firm or called the Agency Theory (Agency Theory) which was popularly introduced by Jensen and Mecking (1976). When the shareholders' representatives, namely the firm's management, manage funds from investors, then they design in such a way by setting an optimal funding strategy by utilizing firm assets to be used as collateral in the form of funds that can be developed for the prosperity of shareholders and the firm's sustainability. These results are in line with research conducted by Nawaz et.al (2011). Therefore the firm is trying to increase its profits then allocate its profits to continue to expand the business.

Based on the results of the research that has been discussed, it increasingly illustrates that the capital structure is measured either through the capital composition of debt and all firm assets or DAR as well as the capital composition seen from a comparison of debt and the perspective of shareholders, apparently has an important role in the firm to make a profit. The right capital strategy will certainly also has an impact on firm profitability.

Such conditions prove that the management of fund management is very important in a firm because it influences the firm's main goal, which is to obtain maximum profit.

\section{CONCLUSION}

The results of the discussion from the above description can be concluded from the study of the Effect of Capital Structure measured through Debt Assets Ratio (DAR) and Debt Equity Ratio (DER) on Profitability measured through Return on Equity (ROE) on firms with sharia criteria in Jakarta Islamic Index (JII) on the Indonesia Stock Exchange in the period 2012 to 2017. Some of the conclusions referred to are as follows:

Based on the research result, Debt to Asset Ratio (DAR) significantly influence the Return On Equity (ROE) of firms listed on the Jakarta Islamic Index (JII) on the Indonesia Stock Exchange for the 2012-2017 Period. The effect is negative or inversely proportional between DAR and ROE. The higher the DAR value, the lower profitability. Conversely, if the DAR decreases, the profitability measured by ROE increases. In other words, the capital structure reflected through DAR has an impact on the firm to achieve the main goal of maximizing profitability in each of its business activities. These conditions support the classical theory of capital structure, namely the pecking order theory. Consequently, the answer from the identification of the problem proposed by researchers is that there is a significant negative effect between the capital structure measured by DAR on profitability as measured by ROE on the best sharia-compliant firms on the Indonesia Stock Exchange for the 2012-2017 period.

The DER variable has a significant positive effect on ROE. This means that the effect is directly proportional. If the DER value increases, the ROE value also increases. Conversely, if the DER value decreases, the ROE value also decreases. In conclusion, the alternative 
hypothesis proposed by the researcher is accepted. These results are in line with research conducted by Asad et.al (2011). Consequently, the firm is trying to increase its profits then allocate its profits to continue to expand the business.

The third hypothesis proposed by researchers, namely the capital structure consisting of the variable Debt to Asset Ratio (DAR) and Debt to Equity Ratio (DER) simultaneously has a positive effect simultaneously (overall) on Return on Equity (ROE) on firms registered in the Jakarta Islamic Index (JII) on the Indonesia Stock Exchange for the 2012-2017 Period. The answer to that hypothesis is accepted. This is because based on testing the simultaneous regression model (Test F) Debt to Asset Ratio (DAR) and Debt to Equity Ratio (DER) simultaneously have a positive effect on Return on Equity (ROE).

The results showed that Debt to Asset Ratio (DAR) and Debt to Equity Ratio (DER) simultaneously had a positive effect on Return on Equity (ROE) in firms listed on the Jakarta Islamic Index (JII) on the Indonesia Stock Exchange for the 2012-2017 period. In addition, the contribution of the influence of DAR and DER to the Profitability measured by ROE is quite large, above $50 \%$, precisely at $66.8 \%$. Such conditions prove that the management of fund management is very important in a firm because it influences the firm's main goal, which is to obtain maximum profit.

Investors who have never invested in Islamic instruments should consider these alternatives. The reason is that in addition to having a strict screening methodology, both in qualitative terms, for example following Islamic sharia rules and quantitative terms such as strong fundamental factors, investment instruments, in this case, Islamic stocks are proven to exceed the performance of conventional shares through LQ45 as a proxy. Investors who already have Islamic instrument preferences in their investment alternatives are expected to consider the firm's capital structure component.

Future studies when taking the same research focus are expected to use a longer observation period. In addition, the variables studied can be reproduced as related to political conditions, industry trends, and business fundamental growth.

\section{APPENDIX - RESEARCH SAMPLE}

\begin{tabular}{|c|l|l|c|c|c|}
\hline No. & Firm Code & \multicolumn{1}{|c|}{ Firm Name } & DAR & DER & ROE \\
\hline 1 & AALI & Astra Argo Lestari Tbk & 0.30 & 0.47 & 20.99 \\
\hline 2 & ADRO & Adaro Energy Tbk & 0.50 & 1.02 & 11.51 \\
\hline 3 & AKRA & AKR Corporindo Tbk & 0.56 & 1.32 & 21.92 \\
\hline 4 & ASII & Astra International Tbk & 0.49 & 0.97 & 20.67 \\
\hline 5 & BSDE & Bumi Serpong Damai Tbk & 0.37 & 0.59 & 14.51 \\
\hline 6 & ICBP & Indofood CBP Sukses Makmur Tbk & 0.36 & 0.55 & 18.45 \\
\hline 7 & INCO & Vale Indonesia Tbk & 0.23 & 0.31 & 5.98 \\
\hline 8 & INDF & Indofood Sukses Makmur Tbk & 0.48 & 0.92 & 12.15 \\
\hline 9 & INTP & Indocement Tunggal Prakasa Tbk & 0.14 & 0.16 & 21.86 \\
\hline 10 & KLBF & Kalbe Farma Tbk & 0.18 & 0.22 & 21.70 \\
\hline 11 & LPKR & Lippo Karawaci Tbk & 0.52 & 1.10 & 9.33 \\
\hline 12 & LSIP & PP London Sumatra Indonesia Tbk & 0.17 & 0.20 & 15.26 \\
\hline 13 & PGAS & Perusahaan Gas Negara Tbk & 0.47 & 0.91 & 27.62 \\
\hline 14 & SMGR & Semen Indonesia Tbk & 0.29 & 0.41 & 23.31 \\
\hline 15 & TLKM & Telekomunikasi Indonesia Tbk & 0.41 & 0.69 & 27.55 \\
\hline 16 & UNTR & United Tractors Tbk & 0.37 & 0.58 & 14.91 \\
\hline 17 & UNVR & Unilever Indonesia Tbk & & 2.06 & 119.47 \\
\hline
\end{tabular}

\section{REFERENCES}

1. An-Nawawi, Imam Muhyiddin. 1428 H/2007 M. al-Minhaj Syarh Shahih Muslim bin alHajjaj, , Cet. XIV, Tahun, Dar al-Ma'rifah, Beirut, IX/379-381.

2. Baltagi, Badi H. 2005. Econometrics Analysis of Panel Data, Third Edition, John Wiley \& Sons Ltd, Chicester.

3. Boopen, Seetanah, Keshav Seetah.2014. Capital Structure and Firm Performance: Evidence from an Emerging Economy. The Business \& Management Review, Volume 4 Number 4. 
4. Brealey et al. 2008, Dasar-dasar Manajemen Keuangan Perusahaan. Edisi 5, Erlangga,

5. Brigham, E.F., and J. Houston. 2001. Manajemen Keuangan. Penerjemah Hermawan Wibowo. Edisi Kedelapan. Edisi Indonesia. Buku II. Jakarta: Erlangga.

6. Brigham, E.F., and J. Houston. 2004. Dasar-Dasar Manajemen Keuangan. Penerjemah Ali Akbar Yulianto. Edisi Kesepuluh. Edisi Indonesia. Buku II. Jakarta: Salemba Empat.

7. Danise, Dickins and Robert, Houmes. 2009. Revisiting the Relationship between Insider Ownership And Perfomance, Journal of Business and Economic Studies. Vol. 15, No. 2. East Carolina Universitas-Jaksonville University.

8. Dwilaksono, Hendri. 2010. Effect of Short and Long Term Debt to Profitability in The Mining Industry Listed in JSX. Business and Entrepreneurial Review Vol.10, No.1 page 77-87 ISSN 2252-4614.

9. Ghozali, Imam. 2013. Aplikasi Analisis Multivariate dengan Program IBM SPSS 21 Update PLS Regresi. Semarang: Badan Penerbit Universitas Diponegoro.

10. Gitman, Lawrance J and Chad J. Zutter. 2012. Principles of Managerial Finance. $13^{\text {th }}$ Edition. Global Edition: Pearson Education Limited.

11. Grais, W., Pellegrini, M., 2006. Corporate Governance and Shariah Compliance in Institutions Offering Islaic Financial Services. Policy Research Working Papers. The World Bank.

12. Green, William H.,2002, Econometric Analysis. Fifth Edition, Prentice Hall, New Jersey.

13. Gujarati, Damodar, 2004, Basic Econometrics, Fourth Edition. McGrawhill-Hill, New York.

14. Gujarati, Damodar N and Dawn C. Porter. 2012. Dasar-dasar Ekonometrika Buku 2. Edisi 5. Raden Carlos Mangunsong (penj.). Jakarta: Salemba Empat.

15. Hasbi, Hariandy. 2015. Islamic Microfinance Institution: The Capital Structure, Growth, Performance and Value of Firm in Indonesia. Procedia - Social and Behavioral Sciences 211 (2015) $1073-1080$.

16. Haron, R., Ibrahim, K., 2012. Target Capital Structure and Speed of Adjustment: Panel Data Evidence on Malaysia Shari'ah Compliant Securities. International Journal Economic Management. Account 2 (2), 87-107.

17. Hsiao, Cheng. 2003. Analysis of Panel Data, Second Edition. Cambridge University Press, New York.

18. Jensen, C. Michael., William H. Meckling. 1976. Theory of the Firm: Managerial Behavior, Agency Costs, and Ownership Structures. Journal of Financial Economics, V.3, No.4, pp. 305-360.

19. Keown. 2004. Manajemen Keuangan: Prinsip-Prinsip and Aplikasi. Edisi 9, Indeks. Jakarta.

20. Modigliani, F., Miller, M.H., 1958. The Cost of Capital, Corporate Finance, and The Theory of Investment. Amarican Economic Rev. 48 (6), 261-297.

21. Moleong, Lexy J. 2007. Metode Penelitian Kualitatif, Bandung: Remaja Rosdakarya.

22. Myers, S.C., 1984. The Capital Structure Puzzle, Journal of Finance. Vol. 39, hal: 572592.

23. Nawaz, Asad, Rizwan Ali, M. Akram Naseem. 2011. Relationship between Capital Structure and Firm Performance: A Case of Textile Sector in Pakistan. Global Business and Management Research: An International Journal, Vol.3 No.3 \& 4 pp 270-275.

24. Nuryaman and Veronica Christina. 2015. Metodologi Akuntansi and Bisnis - Teori and Praktek. Ghalia Indonesia, Bogor.

25. Petersen et.al. 2008. Systematic Mapping Studies in Software Engineering. School of Engineering, Blekinge Institute of Technology, Box 520.

26. Purnomo, Margo. 2015. Pemetaan Sistematis Urban Entrepreneurship. JDM Vol. 6, No. 1 2015, pp: 97-120.

27. Sarwono J and Suhayati E. 2010. Riset Akuntasi Menggunakan SPSS, Graha IImu, Bandung.

28. Sugiyono. 2012. Metode Penelitian Kuantitatif Kualitatif and R\&D. Alfabeta, Bandung.

29. Sugiyono. 2013. Metode Penelitian Pendidikan Pendekatan Kuantitatif, Kualitatif, and R\&D. Bandung: Alfabeta. 
30. Sujarweni, V and Poly Endrayanto. 2012. Statistika untuk Penelitian. Yogyakarta: Graha IImu.

31. Supomo, Bambang and Nur Indriantoro, 2002, Metodologi Penelitian Bisnis, Cetakan Kedua, Penerbit BFEE UGM, Yogyakarta.

32. Tarmizi, Erwandi. 2016. Harta Haram Muamalat Kontemporer. Cetakan XVI. Jakarta: Berkat Mulia Insani.

33. Usman, Muhamad, Sana Saleem. 2015. Impact of Capital Structure on Profitability Empirical Evidence of Non-Financial Firms Listed on Karachi Stock Exchange. The Pakistan Journal of Social Issues, Volume 6.

34. Xu Jin. 2012. Profitability and capital structure: Evidence from import penetration. Journal of Financial Economics, Volume 106, Issue 2, November 2012, Pages 427-446, ISSN 0304-405X.

35. Winarno, Wing Wahyu,.2015. Analisis Ekonometrika and Statistika dengan Eviews. Yogyakarta: UPP STIM YKPN.

36. Yildirim Ramazan, Mansur Masih, Obiyathulla Ismat Bachal.2018. Determinants of Capital Structure: Evidence from Shari'ah Compliant and Non-Compliant Firms. PacificBasin Finance Journal 51 198-219.

37. Zeitun \& Rami. 2007. Capital Structure and Corporate Performance: Evidence from Jordan. Australasian Accounting Business \& Finance Journal, Forthcoming. 